\title{
BRIEF NOTES WITH REFERENCE TO FIVE S.A.A.F. SQUADRONS (1939-1945)
}

Introduction

The following concise notes have been compiled by the undermentioned staff members of the Military Historical and Archival Services (M.H.A.S.) as a special contribution to the golden jubilee of our Air Force and this editon of "Militaria":

a Capt. P. J. Albertse, B.A., Dip. A. and Sgt. P. J. Brink

- No. 3 Squadron, S.A.A.F.

b Sgt. P. J. Brink

- No. 15 Squadron, S.A.A.F.

c Miss C. Bergh. B.A., L.S.T.D.

- No. 25 Squadron, S.A.A.F.

d Sgt. P. J. Brink

- No. 40 Squadron, S.A.A.F.

e Mrs. L. Glatthaar

- No. 41 Squadron, S.A.A.F.

These squadrons are striking examples of the conduct that characterised all the S.A.A.F. squadrons during that time. 


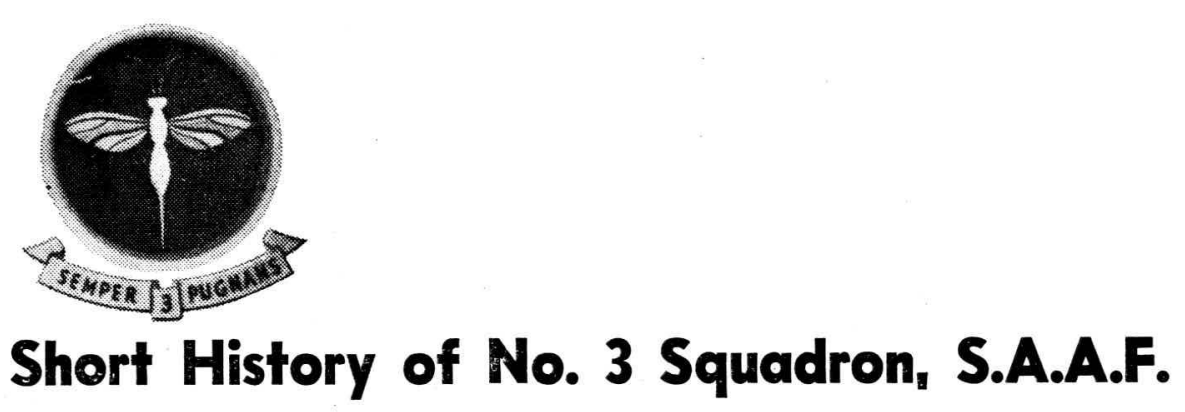

1 With Maj. L. A. Wilmot as Commanding Officer the Squadron was established at Waterkloof Air Station during August/September 1940 and equipped with Hurricanes.

2 The Squadron was divided into a sea party and an air party, the latter travelling in Vickers Valentias and acting as a servicing flight to the Hurricanes on the way up to East Africa.

3 The sea party left from Durban on 15 October 1940 aboard the Durban Castle, and after an uneventful voyage disembarked at Mombassa eight days later, when they immediately entrained for Nairobi.

The Squadron flew its first sortie on October 28, 1940 but it was not until 22 November that Lt. Allen drew first blood by destroying a CA 133, killing five of the crew.

The Squadron's famous crest The Fighting Wasp, with the motto Semper Pugnans was adopted on December 1, 1940, Major Niblock-Stuart taking over the same day, Maj. Wilmot having being posted to the Middle East. At this time Headquarters with "A" Flight was stationed at Nairobi while " $B$ " and " $C$ " Flights were at Garissa and Mombassa respectively.

On February 3, 1941 Capt. Jack Frost bagged five enemy aircraft and on 19 February, was granted the immediate award of the D.F.C. for the feat. Messages of congratulations were received from General Cunningham, General Officer Commanding East African Forces and Air Commodore Sowry Air Officer Commanding East Africa. Soon after this, the great push through Italian Somaliland and Abyssinia started and the Squadron moved to Garissa and experienced its first air raid.

The Squadron had many victories during the latter part of February and the next two months while advancing on Addis Ababa via Afmadu, Kismayu, Mogadiscio, Gorrahai, Dagar Bur, Jiggiga and Dire Dawa. According to the War Diary of No. 3 Squadron, the total enemy aircraft shot down or destroyed on the ground amounted to 100 by April 30, 1941. During this period Lt. Bob Kershaw, later Officer Commanding 7 Squadron S.A.A.F., was awarded the D.S.O. for the daring rescue of Capt. Frost. The latter had force landed at Dire Dawa owing to a glycol leak and although the landing ground was under fire, Lt. Kershaw landed, squeezed Capt. Frost into his cockpit and made a successful getaway. Capt. S. van B. Theron was awarded the D.F.C. The losses of No. 3 Squadron were three pilots killed, 5 aircraft destroyed and 13 aircraft damaged.

Major Niblock-Stuart left the Squadron at Dire Dawa where Maj. J. D. Pretorius took over. Mr. Hiram B. Blauwfeld, an American War Correspondent, filmed the Squadron on 1 May when the 101st victory was gained. Shortly after this the Squadron received ten Gladiators, in very poor shape, but after a good overhaul they proved themselves both as trainers for new pilots and as fighters. 
proceeded to Alamato. From here it moved back to Nanyuki, East Africa, travelling by road through the forest regions during the rainy season. The roads were bad and the journey took 28 days.

At Nanyuki the Squadron was re-equipped with 12 Mohawks and after a few weeks training returned to Alamato. With an advanced Flight at Dabat, the Squadron operated with great success over Gondar and Lake Tana area, using the Mohawks as fighter bombers.

$4 \quad$ After the fall of Gondar and the cessation of hostilities in Italian East Africa the Squadron moved to Asmara where it disbanded after a short stay. From Asmara the personnel proceeded by road to Masawa from where they embarked for the Union.

5 The Squadron was eventually reformed by Capt. C. A. van Vliet and left for the Middle East on December 16, 1942, aboard the Nieuw Amsterdam, from which vessel it disembarked at Suez on New Year's Day.

6 A fortnight later the Squadron re-embarked for Aden where it took over the duties of Fighter Defence until the middle of April, when it returned to the African Mainland with Capt. E. M. Baker in command.

7 The first camp was at Bersis and it was there that most of the pilots had their first taste of operational flying. Three pilots were lost. Lt. Minto's engine cut over a convoy and he went straight in. Lt. Young and Lt. Jackson crashed during night flying and both planes went up in flames.

During June the Squadron moved off to Zuara, a long trek of some eight hundred miles. There was less operational flying to do, but at least some of the Squadron's machines gave air cover to part of a large convoy which steamed out of Tripoli harbour to invade Sicily. The stay at Zuara lasted just over two months; the Squadron had lost one pilot, Lt. van der Wath. The weather for the most part was trying; blinding sandstorms and temperatures around 120 degrees $\mathrm{F}$.

The next move was to Mellaha on the outskirts of Tripoli; here the Squadron was very comfortably billited and had a wonderful time. There was practically no operational flying and No. 106 South African General Hospital was in the vicinity. During this period the C.O., Maj. Baker, who was later to become famous, left to take over 5 Squadron and Maj. Wiggett was appointed in his stead. Perhaps the highlight of the Squadron's stay at Mellaha was that twelve of its aircraft escorted General J. C. Smuts from Tripoli to Ben Gardane on his way to London.

At the end of October the Squadron received instructions to return to their old camping site at Bersis. It so happened that, before " $B$ " party could join forces, orders were received for a further move to Savoia.

The new aerodrome, which was constructed by New Zealanders, was laid out in a hollow and this fact was later to prove the cause of considerable trouble during the rainy season.

Nevertheless, towards the end of November No. 3 Squadron was equipped with sixteen brand new Hurricane II C's and on 29 November four were scrambled to intercept enemy aircraft attacking a convoy and Capt. Yeats bagged half a J.U. 88; the other half going to a 41 Squadron pilot flying one of No. 3 Squadron's machines, and Capt. Geldenhuys got a probable - all without loss to the Squadron.

From then on little happened apart from the usual shipping cover but in February the Squadron was suddenly equipped with sixteen Spitfires Mark IX and 
on the morning of 29 February (it was fortunately a Leap Year) Lt. R. du Preez and Lt. H. Geater were scrambled after a recce J.U. 88, each obtaining a half over Derna.

In March the Squadron were instructed to hand over the Mark IX's to 7 and 41 Squadrons and were given Spitfires Mark V in lieu. Operational commitments dwindled thereafter and the Squadron were finally moved to the delta towards the end of July.

8 A short stay at Base Depot and a very pleasant trip across Italy finally saw the Squadron ready to undertake fresh operations under the newly formed

8 Wing S.A.A.F.

On arrival in Italy most of the pilots were attached to 7 Wing to gain fighter-bomber operational experience. After a few weeks during which the Squadron was re-equipped, the Squadron began operations in 8 Wing S.A.A.F., under the leadership of Maj. Dunning, the Squadron carried out its first mission in 8 Wing, on October 13, 1944. From then until 18 November the Squadron operated under D.A.F., but on 19 November, the Wing was attached to 22nd T.A.C. in support of the 5th Army and proceeded to operate from Florence until 1 January 1945 when the Squadron moved to Pontedera landing ground.

The Squadron flew almost 2300 sorties in Italy up to April 20, 1945 for the loss of 2 pilots killed and 3 missing. In support of the 5th Army's current offensive the Squadron put up a record number of 54 sorties in a day, despite the fact that there was no flying for four hours during the day whilst heavy bombers were operating over the lines.

9 After the war No. 3 Squadron was disbanded, but on Saturday, September 6, 1952 this famous fighter squadron again came into existence as an Active Citizen Force (A.C.F.) Squadron with Maj. Dan Tilly as Officer Commanding.

10 Commanding Officers

Maj. L. A. Wilmot : September, 1940-November, 1940.

Maj. N. C. Niblock-Stuart : December, 1940-April, 1941.

Maj. J. D. Pretorius : April, 1941-May, 1941.

Maj. C. C. van Pittius : May, 1941-November/December, 1942.

Maj. C. A. van Vliet, D.F.C. : December, 1942-March, 1943.

Capt. E. M. Baker : April, 1943-August, 1943.

Maj. B. A. A. Wiggett : August, 1943-May, 1944.

Maj. E. K. Dunning : May, 1944-December, 1944.

Capt. C. A. Golding : December, 1944-October, 1945.

11 Battle Honours

Indian Ocean/Indiese Oseaan 1943.

East Africa/Oos-Afrika 1940-41.

The Juba/Die Juba.

Addis Ababa.

The Lakes/Die Mere.

Mediterranean/Middellandse See 1943-44.

Italy/Italië 1944-45.

Gothic Line/Gotiese linie.

$\mathrm{Po} /$ Appenines / Appenyne. 


\section{$z$ \\ Short History of No. 15 Squadron, S.A.A.F.}

1 No. 15 (Bomber) Squadron, S.A.A.F., was originally formed from No. 5 (Bomber Fighter) Squadron, S.A.A.F. with effect from December 1, 1939. On May 16, 1941, the Officer Commanding, Maj. H. H. Borckenhagen, issued the movement order to Zwartkop Air Station to detail personnel to proceed to Nairobi by train and road convoy to join their Squadron there. From June 1, 1941 all the remaining personnel of No. 11 Squadron were absorbed into No. 15 Squadron under the command of Maj. Borckenhagen. Its operational functions were to consist mainly of bombing and reconnaissance patrols.

2 On June 11, 1941 a signal was received for all personnel to move to Addis Ababa. Several officers and the main convoy under Capt. Cowan arrived at Addis Ababa on the 13th and stayed there until 19 June when they returned to the camp at Algato. Due to heavy rains patrols were sent to Combolchia on the 29 th. On 5 August instructions were received to move the base to Alomata. The Squadron left the next day and on 8 August the ground party proceeded through rugged country over the Mussolini pass to Combolchia, reaching the camp at Alomata satellite aerodrome on 10 August - four days after the aircraft. On 24 August the camp was broken up and taken to Alomata main aerodrome. On 30 August the departure for Nairobi began when the convoy left Addis Ababa. On 14 September the ground personnel left for Mombassa by train whilst the aircrews proceeded by aircraft. The personnel embarked on S.S. Sontay at Mombassa on the 26th for Durban. They disembarked at Durban on 8 October and set off for Pretoria where they arrived on the 9th. By the 10th the aircraft arrived at Germiston via Broken Hill and the Squadron personnel obtained leave from the Mobile Air Force Depot at Voortrekkerhoogte.

3 The Squadron thus became non-operational and flying training was carried out during November and December. Conversion to Maryland aircraft, taken over from 71 Flight, also took place while the Squadron prepared itself at Germiston. On January 19, 1942 the Squadron left for Durban where they embarked on the Elizabethville and H.M.T. Llandaff Castle on the 20th. They arrived at Aden on 3 February and left again on the 7th for Suez, where they arrived on February 13, 1942.

4 The Squadron's history in the Middle East commences with its arrival at Amriya on February 14th, 1942. On the 26th February the first Blenheim aircraft arrived for training purposes and by the end of the month the Squadron was in possession of nine aircraft for the Blenheim conversion. From the 1st to 25th March the Squadron had nineteen serviceable aircraft, and was thereafter located at landing ground No. 98 where it carried out its training programme.

On 23rd April No. 15 Squadron provided a Guard of Honour to H.H. The Duke of Gloucester at the Base Camp. Four days later three aircraft left to form a detachment under 203 Group at Kufa. The ground party had already arrived at Kufra on the 25th. Kufra oasis was situated 400 miles behind the Squadron's front and 100 miles inside enemy territory. The detachment's role was to protect the flank from unexpected attack by possible enemy armoured desert raiding parties 
and to give advance notice of any unusual enemy activity in that area. One of the most harrowing disasters in the history of the S.A.A.F. occurred in the first week of May when three Blenheim aircraft of the detachment, making their first reconnaissance from Kufra did not return after a patrol flying. After an intensive search all three aircraft were finally located on 11 May. With one exception, Air Mechanic N. St.N. Juul, the crews, including the Officer Commanding Detachment, were dead. On 4 June the base party was sent to landing ground 100 and on 30 June the Squadron, now equipped with Blenheim Mark IV's, arrived at Bellah to continue its training. On 31 July the Squadron moved to Mariut where it was to be based for the purposes of coastal reconnaissance, under No. 201 (Naval Co-operation) Group.

In August the Squadron commenced active operations and on the 8th the first operational shipping patrol was carried out. On 4 August the detachment at Kufra. where it had been operating since the end of April, was replaced by an entirely new detachment. The Squadron's most important operation came at the time when Field Marshal Rommel urgently needed his supplies and fuel for his Panzer Army in North Africa. On the afternoon of October 25, 1942 No. 201 (Naval Co-operation) Group received word that an Axis convoy, consisting of a tanker, two cargo ships and four destroyers, was approaching the Libian coast. That night R.A.F. bombers attacked the convoy, but without success. No. 201 Group Headquarters planned an attack by No. 15 Squadron and by torpedocarrying Beauforts of Nos. 39 and 47 squadrons. At 1235 hours on 26 October five Bisleys of this squadron took off from Gianaclis, near Alexandria, with the instruction to sink the tanker at all costs. It was afterwards learnt that this tanker was called the Proserpina. The Bisleys were to attack first. A section of the two Bisleys, flown by Maj. D. W. Pidsley and Lt. E. G. Dustow decided to attack from the landward side as the ships were sailing parallel to the coast. Lt. Dustow turned more sharply than his leader and sped in to attack the tanker slightly ahead of Maj. Pidsley. Unfortunately one wing struck a mast, after anti-aircraft had hit his aircraft, and he crashed into the sea. Maj. Pidsley succeeded in dropping his four bombs right across the tanker's bridge from a height of about twenty feet, and just avoided hitting the funnel. The last view of the tanker was of the bridge being blown into the air and black smoke pouring from the stern. From a prisoner of war source it was stated that the 9000 ton tanker had been carrying petrol which had been so urgently needed and so eagerly awaited that German commanders were standing on the cliffs to watch it come into Tobruk, only to see it destroyed before their eyes.

On 1 November Maj. Pidsley, the Acting Officer Commanding, was awarded the Distinguished Flying Cross (D.F.C.) for his part in the tanker operation. On 17 November an advanced flight of four Bisleys was sent to Gambut to carry out anti-submarine patrols over convoys to and from Malta. They were under control of No. 247 Wing. On 27 November the detachment at Kufra was withdrawn whilst the advanced flight at Gambut returned to Mariut on 29 November. By December 1942 the squadron was stationed at Mariut with a detachment at Gambut.

A new commitment was undertaken by the end of January 1943 when anti-submarine patrols were carried out east of Cyprus on the 26th, 27th and 28th, using Nicosia (Cyprus) as an advanced landing ground. During February further awards had been made for the sinking of a tanker on 26 October, when Lieutenants J. A. Lithgow and M. M. Yudelman received the D.F.C. On 6 May the advance party left for landing ground 91 and the main party arrived there on 7 May. Throughout June 1943 anti-submarine patrols and convoy escorts were carried out and patrolling was done as far as Haifa. On 1 July four Baltimores were de- 
tached to St. Jean (Palestine) under command of Capt. Cromhout. On 15 July Lt. Col. Pidsley, D.C.F., departed and Maj. D. V. Dodd took over the acting command of No. 15 Squadron until the arrival of Lt. Col. D. E. D. Meaker, D.F.C. By the end of the month the squadron had been completely converted from Bisleys to Baltimores. The advance party for the squadron's move arrived at landing ground 07 on August 3, 1943. Assistance in operational sorties was given to No. 13 Hellenic Squadron by aircraft at Gambut on several occasions during August, and on August 27 the first South African Air Force reconnaissance over the Aegean islands was flown by the squadron. On 10 September a further detachment was sent to Gambut to assist No. 13 Hellenic Squadron. On 21, 24 and 25 September the squadron carried out raids on enemy aerodromes at Heraklion (Crete), Maleme and Kastelli Padadia respectively. This was the forerunner of more offensive tactics on a larger scale than the squadron had hitherto been allowed to employ and during the month many caiques were attacked and offensive reconnaissance made into the Aegean.

During October the squadron continued its offensive tactics and made many attacks on shipping. On 1 October aircraft of the squadron convoyed the battleships King George $V$ and Lord Howe. Owing to the successful strikes by the squadron, it was found that shipping appeared to travel by night in order to avoid aircraft. From the beginning of November, therefore, the squadron commenced a series of strikes at harbours and inlets where shipping might lie concealed. H.M.S. Renown was escorted by squadron aircraft on 21 November. During the second half of the month the squadron also began to encounter determined opposition from enemy night-fighters and ack-ack. For the first time in its history the squadron exceeded 1000 flying hours for the month. On February 20, 1944 the detached flight returned from Gambut. On 1 March all squadron aircraft were sent as detachment to St. Jean for five days. On 9 March 16 aircraft and ground personnel went on detachment to Ramat David.

During the month or March many new crews also arrived at the squadron and a large number of the ground crews returned to South Africa. The squadron had also been notified of the awards of the D.F.C. to Maj. C. Cormack and Lt. N. G. Gould and the Distinguished Flying Medal (D.F.M.) to Flight Sergeant J. M. Julian. In April 1944 the squadron was moved to Gambut. The main party from Matruh West arrived at Gambut on 13 April. Four aircraft remained at Matruh West for convoy escort. No. 15 Squadron had been the only general reconnaissance squadron covering the Mediterranean coast between Alexandria and Benghazi. During April the squadron was called upon to assist in suppressing the Greek revolt in the delta area. They made dummy runs over a Greek cruiser in Port Said but dropped no bombs. During May the squadron continued its convoy escorts, training as anti-submarine patrols from Gambut to Matruh West until the detachment at Matruh West returned to Gambut on the 15th. The squadron had also been notified of the award of D.F.C. to Maj. M. C. Howson.

5 July 1944 marks another milestone in the history of No. 15 Squadron when 235 members left Gambut for Almaza on the 17th for embarkation to Italy. The remaining 110 personnel left with the aircraft, tentage and surplus personnel. The ground party arrived at Taranto on the Italian coast on 1 August and the transport party at Bari on 6 August. The whole party left for Falconara on 11 August. When the squadron, now together with No. 454 R.A.F. and No. 500 R.A.F. squadrons under No. 253 Wing, arrived at Falconara the bombing line was south of Fano. This area was known to have the highest incidence of malaria in the whole of Italy. However, the squadron settled down and carried out excel- 
lent bombing. Further awards of the D.F.C. were made in September when Capt. A. J. van Amerongen and Lt. L. G. van Renen received this decoration. Due to heavy rains the terrain bordering the airfield had become a quagmire during October and November and operations were carried out under difficult circumstances. This, however, did not prevent the squadron from continuing its excellent work for, while operating under the Balkan Air Force and Desert Air Force, an escort vessel and one 4000 ton merchant ship were sunk in Fiume harbour on 5 November and an "F" Boat was sunk on 6 November. During the first week of December the squadron moved from the mud of Falconara to the newly constructed aerodrome at Cesenatico. The squadron again had the distinction of having the most advanced aerodrome in Italy being within a few miles of the front. The move to Cesenatico was completed by 9 December. During December, 1944 and January, 1945 the controlling factor in the squadron's operations and training was the weather which was the worst ever experienced by this squadron, but despite this a great amount of flying was carried out. In January training for night operations was done. On 18 January the last operation of the month was carried out. The targets included marshalling yards in Northern Italy, gun, troop and tank concentrations and Kesselring's Headquarters at La Pastorella. From 19 January the training and conversion programme was continued and practically the whole of February was devoted to night flying training.

$6 \quad$ On May 9, 1945 the Germans surrendered unconditionally and so the European holocaust came to abrupt end. It had been a long trek from South Africa through Abyssinia, the Western Desert, Cyrenaica and Italy to the borders of Austria and Yugoslavia. During April it was rumoured that the squadron would make one more move in Italy. On 7 May instructions were received to move to Udine in North East Italy. By 24 May the move was finally completed. On 16 July instructions were received from Desert Air Force to stand down, to hand in all aircraft, technical and other equipment and to prepare to proceed by road with all personnel to Lecce, south of Brindisi in the heel of Italy. The long trek to the south commenced on 30 July. On 7 August the squadron moved from Lecce to Bari Transit Camp. On 9 August the squadron finally wound up the targed date given for the squadron to cease to exist in name.

7 Commanding Officers

Maj. (later Lt.-Col.) H. H. Borckenhagen : June 1941-September 14, 1942.

Maj. D. W. Pidsley : acting with effect from September 15, 1942.

Lt.-Col. D. W. Pidsley, D.F.C. : December 28, 1942-July 13, 1943.

Maj. D. V. Dodd : acting with effect from July 14, 1943.

Lt.-Col. D. E. D. Meaker, D.F.C. : September 19, 1943-October 14, 1944.

Lt.-Col. C. Cormack, D.F.C. : October 15, 1944-November 16, 1944.

Lt.-Col. L. H. G. Shuttleworth, D.F.C. : November 17, 1944- March 26, 1945.

Lt.-Col. W. S. Clark, D.F.C. : March 27, 1945-August 9, 1945.

\section{Battle Honours}

East Africa/Oos-Afrika 1940-41.

The Lakes/Die Mere.

Western Desert/Westelike Woestyn 1941-43.

Gazala.

El Alamein.

South East Europe/Suidoos-Europa 1943-45.

Italy/Italië 1943-45.

Gothic Line/Gotiese linie.
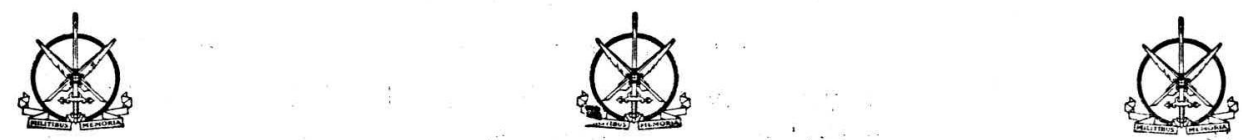


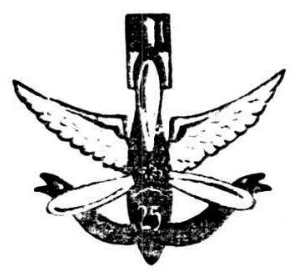

\section{Short History of No. 25 Squadron, S.A.A.F.}

\section{Short History}

a A study of official records reveals that 25 Squadron, S.A.A.F. was formed in Port Elizabeth on July 1, 1942, but in fact the first page of the Squadron's history was written on the outbreak of war. At that time it was known as 33 Coastal Flight; this eventually became 25 Squadron.

It can hardly be said that 25 Squadron was "formed," rather that 33 Flight expanded and was given the status and name of a Squadron. The nature of the work remained unchanged and it was only some time after the demise of 33 Flight that the trusty old Ansons which had been used from the beginning were replaced by what the aircrews then considered the height of modernity - Ventura B. 34 Mark I's.

At the outbreak of war, flying crews were made up of reservist pilots: Officers who had gained their wings during peace time and placed on the reserve, together with some pilots drawn from the small regular Air Force. In those days coastal reconnaissance was carried out without observers or gunners. Each crew consisted of two pilots one of whom did the navigating.

The first Officer Commanding, 33 Flight was Maj. Rademan and he had six Ansons and about 80 personnel members under his command.

Regular morning and afternoon patrols were carried out along the coast of Port Elizabeth. Day by day the coastline was patrolled for about eighteen months. There was no excitement and no glory; nothing to relieve the monotony of the work. November 4, 1941 was probably the only outstanding date in the annals of 33 Flight. On this day the Flight's Ansons took over from S.A. Minesweepers the escort of a convoy of Vichy ships which had been intercepted and captured. There were five merchantmen in the convoy, protected by a sloop which escaped when the other vessels surrendered. The escort was completed on 6 November.

After this episode, patrol activity continued as before. A further uneventful eight months of long sea patrols terminated in the announcement that 25 Squadron was to be formed absorbing 33 Flight. The Flight was temporarily stationed in Durban, but was brought back to Port Elizabeth to form the nucleus of 25 Squadron. The Squadron expanded when observers, gunners and additional ground crews were posted to it. Ventura aircraft were ferried down to Port Elizabeth from Germiston airport, but as none of the pilots on strength had undergone a conversion course, the ferry pilots operated with the Squadron, while the Anson pilots converted. The conversion course was a hurried affair - no ground ininstruction, a little dual, one circuit solo, and one became a Ventura pilot. In spite of this, subsequent mishaps due to lack of training were negligible.

The first Officer Commanding, 25 Squadron, was Maj. C. H. Beyers who stayed only two months. He handed over to Maj. K.S.P. Jones. During this period coastal reconnaissance continued with several variations. Anti-submarine 
patrols were carried out, but it was only in November, 1942 that the first submarine sighting was made by Capt. Visser, whose attack was unsuccessful. The routine anti-submarine patrols were subsequently abandoned and were made only when a sinking or a sighting occurred.

During February, 1943 the Squadron moved to its own aerodrome at St. Albans some 20 miles away. This aerodrome had just been completed and was far superior to their previous one. A Flight of Catalina's was attached to the Squadron from 321 Squadron of the Royal Netherlands Naval Air Force. The Catalinas did all the night work and it was not necessary for the Venturas to fly at night until November, 1943, when the amphibians were withdrawn.

The servicing of aircraft was still undertaken at Port Elizabeth where a fair number of grond staff was stationed. Aircraft were flown over for inspection from St. Albans and East London, both some 160 miles away.

In order to cover as much coastline as possible the Squadron sent a flight to Komgha under the command of Maj. Nash. Later the flight was placed under the command of Capt. Freeman who eventually operated from the far more suitable aerodrome at East London. The aerodrome at Komgha was primitive and appeared to be the favourite grazing pasture for all the cattle in the vicinity. The flight at East London was subsequently placed under the command of Maj. Shuttleworth. As the aerodrome at East London was too small for the Venturas to operate from at night, the Squadron's remaining Ansons carried out the night patrols from there. It was at a point, four hours sailing from East London, that Maj. Shuttleworth who was giving cover to the Dutch ship, the Colombia, of 15000 tons, saw her sinking. The ship had been in East London for six months being refitted as a submarine depot ship.

After March, 1943, convoy escort was more or less abandoned and the Squadron gave escort only to warships and troop carrying convoys. During March however Lt. Benson made an attack on a submarine causing damage to the periscope and conning tower.

The Catalinas were withdrawn in November and the Venturas were inaugurated for the first time. The pilots and crews were obliged to do a bit of training to get into night flying again.

Maj. Jones left the Squadron in November, 1943, to join No. 5 Wing on shuttle service duties. He was succeeded by Maj. E. M. Lewis. This was his first command. Maj. Lewis probably found coastal work uninspiring after a hectic tour on Marauders and left the Squadron early in the following year to go on to Catalinas. Command of the Squadron was given to Maj. Shuttleworth who had just returned from East London with the Flight he was commanding. Maj. Shuttleworth had by this time been with the Squadron for a considerable period and knew the work and the men under his command.

The following year new aircraft, P.V.I's, were added to the Squadron. On the Squadron's departure to Italy the P.V.I's were withdrawn and B.34's were taken back into service. About this time rumours had it that the Squadron was to move overseas, but whatever plans existed were delayed by heavy sinkings off the Cape.

Instead of the anticipated move, only about half of the Squadron's personnel were withdrawn to form the nucleus of new Squadrons. Most of the men were stationed with No. 31 Squadron, S.A.A.F., working on Liberators while aircrews were spread among other Squadrons. 
"Swamp" operations were introduced. For 25 Squadron this meant that aircraft had to become airborne at a moment's notice to reinforce other coastal Squadrons and vice versa. The "Swamp" operations took the machines to bases 600 miles north and 400 miles south of Port Elizabeth. It was on the first of these in January, 1944 that the Squadron suffered its first casualty. One machine crashed into the hills on a particularly stormy night killing Lt. Marrillier and his crew.

Success on these "Swamp" operations was achieved in March, 1944, on an anti-submarine patrol from St. Albans. Normal information had it that two U-boats would round the Cape and the Squadron subsequently sent out patrols, reinforced by aircraft from 22 Squadron. One of the submarines was severely damaged when she was sighted and attacked by Lt. Evans. The search was continued for some days, but later the Squadron's aircraft moved to operate temporarily from Cape Town. The damaged submarine was eventually sighted again and sunk by a Catalina of 262 Squadron. Due to adverse weather conditions and the fact that some aircraft were sent out as far as latitude $42^{\circ}$ south two machines were lost, but the crews returned to safety.

Although the work done in South Africa lacked the thrill of combat or the tense expectancy of bombing, flying conditions were nevertheless difficult.

Until comparatively recently wireless facilities were poor. There was no system of giving fixes and bearings were unreliable. Furthermore the part of the coast patrolled by the Squadron was notorious for its bad weather.

During March rumours had it that the Squadron was about to move and this time it was supported by the posting of large numbers of ground personnel. By the beginning of April the strength of the Squadron was back to its original establishment.

b On April 12, 1944 a despatch came through that the Squadron had to prepare to move out of the Union. This was the news for which they had been waiting a very long time. Operations ceased almost immediately and everyone assisted wherever possible. A large amount of work was done in record time. One half of the personnel proceeded to Italy by sea while the others flew to the Middle East and then on to Italy in the Squadron's Venturas. Due to various difficulties the Squadron arrived at Pomigliano near Naples, only some two months later. The flight from the Union was a notable success. There were no mishaps in spite of the fact that the aircraft were old and that the territory and aerodromes were unfamiliar to the crew.

Operations under M.A.C.A.F. (Mediterranean Allied Coastal Air Force) were cancelled before they began as the submarines no longer existed in the Mediterranean. Instead, the Squadron did operational training for light bombing. They were reinforced by extra crews from 608 Squadron, R.A.F., whom our pilots first converted to Venturas. At the end of August, 25 Squadron moved into Balkan Air Force Command. The first raid took place on August 30, 1944 almost three months after leaving South Africa.

During September, 1944, forty missions were flown representing 243 operational sorties, the total operational hours being 609. The Squadron was still stationed at Campomarino. During October. 1944, the Squadron participated in capturing Corfu. The fact that during November only a quarter of the previous month's tonnage of bombs was dropped illustrates the extent to which operations were hampered by bad weather conditions. By the end of December, 1944, partisan sources reported having counted 1000 destroyed or abandoned motor transport vehicles on the road between Bioce and Kolasin. A total of 678 sorties was flown and flying hours totalled 1729 . 
The Squadron was still stationed in Biferno in January, 1945. Four Marauders which were added to the Squadron, bringing the total to sixteen aircraft. In February 25 Squadron was moved to Campomarino. The Squadron was able to send off its Marauders on 19 days that month, bombing on 16 occasions. During April operations were directed chiefly against railway communications in Yugoslavia. Harbour installations were also bombed, as well as gun positions on various Dalmation islands prior to partisan landings. The Squadron executed its last bombing raid on May 4, 1945 when their first aircraft was lost due to enemy action. Right up to the last day of the war, the Squadron was operated against German strongpoints in Yugoslavia. Compared with the majority of S.A.A.F. Squadrons, 25 has had a short operational career "up North." As a bomber squadron in Balkan Air Force, it had its full share of the daily work on hand.

On June 26, 25 Squadron received an order to disband by July 15, 1945. By that date, the Squadron would have been in existence for three years and two weeks.

\section{Commanding Officers}

Maj. C. H. Beyers : July 1, 1942-September 13, 1942.

Maj. K. S. P. Jones : September 14, 1942-November, 1943.

Maj. E. M. Lewis : November, 1943-January, 1944.

Maj. H. G. Shuttleworth : February, 1944-November 28, 1944.

Lt.-Col. C. Cormack : November 29, 1944-February, 1945.

Maj. G. C. H. Freeman : March, 1945.

Lt.-Col. S. L. Bosch : April 1, 1945-July, 1945.

\section{Battle Honours}

South African Waters/Suid-Afrikaanse Waters 1939/45.

South East Europe/Suidoos-Europa 1943/45.

Sicily/Sisilië 1943.

Italy/Italie 1943/45.

Po/Appenines/Appenyne. 


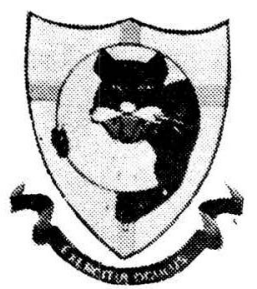

\section{Short History of No. 40 Squadron, S.A.A.F.}

1 Date and place of establishment May, 1940.

Waterkloof Air Station.

2 Commanding Officers

Maj. J. T. Durrant : May, 1940-August, 1941.

Lt.-Col. E. Biden : August, 1941-August, 1942.

Lt.-Col. C. M. S. Murray-Gardner : August, 1942-April, 1943.

Lt.-Col. J. P. D. Blaauw : April, 1943-August, 1943.

Lt.-Col. W. A. Nel : August, 1943-August, 1944.

Lt.-Col. R. H. Rogers : August, 1944-disbandment in May, 1945.

\section{Short notes on the history of No. 40 Squadron}

a Formed at Waterkloof Air Station, South Africa, in May, 1940 as an Army Co-operation Squadron.

One Flight equipped with Hartebeest aircraft left South Africa in June, 1940, for Wadjir, Kenya. The remaining two Flights equipped with the same aircraft followed soon after.

The Squadron went into operations against the Italians, and their main tasks were tactical, photo and armed reconnaissance. In August, 1941, having supported the 1st South African Division, the whole Squadron returned to the Union to re-equip.

Fully re-equipped the unit left South Africa on November 7, 1941, for the Middle East to meet the pilots who had flown there earlier on. While awaiting aircraft in the Middle East, the Squadron became an advanced maintenance unit at Burg El Arab, until February 2, 1942, when Hurricane Mark I's were flown in.

The crews were trained there and on 18 February the Squadron moved to landing ground 117 in the Western Desert to continue training. On March 17, 1942, "C" Flight moved to El Adem with two Hurricanes and one Tomahawk. Meanwhile six pilots gained valuable experience with 208 Squadron, R.A.F. On March 20, 1942, the Squadron began operating on its own, in support of 13 Corps doing tactical and photo reconnaissance.

Casualties were heavy, due to action of enemy aircraft. It was eventually decided to provide fighter escort for all tactical reconnaissance flights. This proved to be very successful, and was continued, until the German breakthrough near Bir Hacheim in June when escort for all tactical reconnaissance flights was stopped. On the first afternoon of the German offensive the advanced landing ground at El Adem was surrounded by German tanks which shelled it until dusk. All serviceable aircraft were flown back to the base at Sidi Azeiz. The Squadron was then moved into the Tobruk perimiter and operated from there until a few days before the town fell.

During the retreat to El Alamein the Squadron never remained at any landing ground longer than a few days and owing to the disruption in communica- 
tions very few sorties were flown. During July the Squadron operated from Burg El Arab and at the end of the month was withdrawn to Quassassin and then El Firdan for re-equipment. In August new Hurricane Mark II's were flown in. Crews were trained in September and during the first half of October.

On 20 October the Squadron moved up to Burg El Arab for the Battle of El Alamein. It was attached to the newly formed 10 Corps that was preparing to make the break-through.

The attack on the Agheila Line was successful and the Squadron moved up to Marble Arch about the middle of December where it remained until after Christmas. During the first half of January long range tactical reconnaissance flights were carried out with Kittyhawk escort behind enemy landing grounds but as the losses were not considered worth while they were cut down to normal battle area missions. The Squadron moved to El Chal and Hamreat before the attack on Wadi Zam Zam and then to Sedada, Darragh West and finally Castel Benito when Tripoli was captured.

As the army progressed from Tripoli in February the Squadron moved from Castel Benito to El Asa, Neffatia Main, Neffatia Sattelite and finally Bou Grara, 15 miles behind the Mareth Line.

After the Mareth Battle, the Squadron moved to Gabes for the breakthrough to Wadi Akarit and then to La Faucannaire and Goubrine (Tunisia).

At the end of the North African Campaign the Squadron returned to Ben Gardan and later to Sorman prior to its departure for Malta.

b Two flights departed from Ben Gardan in North Africa for Luqa Aerodrome, Malta, at the end of June 1943 to carry out operations in preparation for the Sicilian invasion using Spitfire V's. An advance party moved over to Casabele landing ground, Sicily, a few days after the beach-head had been established and were later joined by the remaining Malta party. At short intervals they moved to Lentini West and Francesco following the army.

c The Sicilian Campaign ended 18 August and the Squadron commenced longe range recces of the toe of Italy and low level oblique photography of the Italian coast. A number of naval artillery reconnaissance was also carried out on gun positions in the toe of Italy. On 31 August the Squadron had the honour of carrying out shoots with H.M.S. Nelson and H.M.S. Rodney.

d On 7 September the Squadron ceased operations and were to be withdrawn to North Africa for rest and re-equipment. Before this move could have been completed however, a flight was flown over to Grottaglie landing ground in Italy in 10 DC's escorted by the Squadron's Spitfires and recommenced operations. This flight was under the operational control of 329 Wing, R.A.F., for whom numerous "Pathfinder" tactical reconnaissance flights were carried out. The Squadron succeeded in either destroying or damaging a considerable number of enemy motor transport, guns and enemy equipment during this period. On 23 September the flight moved to Bari landing ground and on 5 October it moved to Foggia Main. On 18 October 13 Corps, 8th Army, as a result of three tactical reconnaissance flights carried out, signalled "Three' magnificent efforts. Many thanks, much appreciated."

The base party moved to Sorman on 30 June where they remained until 10 October, when they moved to Philippeville. Here they remained until 5 December when they proceeded to Bizerta where they embarked for Italy. 
and the North Africa party rejoined the Flight at Foggia No. 1 on 19 December. The entire Squadron was reunited at Trigno in the middle of January 1944. A Flight was sent to Lago landing ground on 26 February to operate in conjunction with 225 Squadron, R.A.F. in support of the 5th Army. Operations were carried out in the area west of and including the Cassino-Rome road embracing Rome itself and the Anzio beach-head.

The Flight rejoined the Squadron as a whole at Marchinese landing ground on 2 April, followed by another move to San Angelo on the 26th.

The entire Squadron was now operating with the 5th Army which was the first time it had ceased to operate in support of the 8th Army, since El Alamein.

Missions were carried out in support of the Gustav Line offensive. On 22 May the Squadron moved to Venafro landing ground. During June a detachment was sent over to Corsica to operate with gun boats of the Royal Navy during the invasion of the Island of Elba - some very successful naval shoots were conducted.

On 25 August the Squadron moved back to the 8th Army front and operated from Chiaravelle in support of the attack on the Gothic Line.

On 1 September the Squadron establishment was reduced from three flights to two, which was the normal R.A.F. establishment for a Fighter Reconnaissance Squadron.

On 2 September the Squadron moved to Piogiolino and later during the month to Cassandra then to Rimini. While at Cassandra one flight operated from Iesi owing to the unserviceability of the former landing ground.

The Squadron moved from Rimini to Bellaria and on 5 December to Forli landing ground where it remained throughout the winter. Long range reconnaissance flights with Spitfire escort were carried out in the Treviso area.

On December 9, 1944, four pilots flying Spitfire V's taken over from 318 Polish Squadron were detached to the Balkan Air Force for operations in Greece against the Elas. Based on Kalamaki aerodrome near Athens the detachment carried out 73 missions.

On 9 April the great battle to smash the enemy south of the Po began and continuous cover of the battle area and north of it by tactical, artillery and photo reconnaissance produced excellent results.

After acting as the "Eyes of the Army" for five years the Squadron took fair toll of the enemie's retreating columns. As the enemy retreated so the Squadron moved and on 2 May operations began from Russia landing ground in the Ferrara area. Another move was made to Treviso landing ground on the 6th.

The enemy's retreat became a rout and at 00.01 hours on May 9, 1945, all the German armies in Italy surrendered unconditionally. However, this Squadron - the only one in Desert Air Force - continued to operate throughout the succeeding victory celebrations and continued to do so until all enemy movement in North Italy and Austria had finally ceased. The work consisted chiefly of tactical reconnaissances of German movement north of the 8th Army and between the advancing American and Russian forces.

f On 14 May the Squadron moved to Risano landing ground in the Udine area and on the 27th became stationed at Mollendorf landing ground, Austria, thus being the first complete unit of the entire Union Defence Force to be stationed in pre-war German occupied territory. 
Due to suspicions entertained by the army regarding the Yugoslav question the Squadron flew daily sorties along the Yugoslav-Austrian border. When it was no longer necessary to watch the activities of the Yugoslavs, a training programme was undertaken in order to maintain the general standard of flying efficiency.

Towards the end of August the Squadron left the control of 285 Wing, with whom it had been since the battle of El Alamein, and it joined 324 Wing.

With the approach of winter the Squadron moved to the recently constructed all-weather landing ground at Klagenfurt on 12 September. On 14 September 4 R.A.F. pilots with 4 Spitfire XI's were attached to the Squadron for the purpose of carrying out high-level photography of the province of Steiermark. In the meantime the Squadron completed oblique photo coverage of prominent valleys, road and rail bridges in the province of Carinthia. On October 20, 1945 the Squadron handed over all aircraft and equipment to 225 Squadron, R.A.F. and left for Bari en route to South Africa on October 22nd.

Thus after 5 years and 5 months a Squadron with a proud record and wonderful achievement was now a name only.

\section{Battle Honours}

East Africa/Oos-Afrika 1940/41.

The Lakes/Die Mere.

Western Desert/Westelike Woestyn 1942-43.

Gazala.

El Alamein.

French North Africa/Frans Noord-Afrika 1943.

El Hamma.

Tunis/Tunisië.

Mediterranean/Middellandse See 1943-44.

South East Europe/Suidoos-Europa 1944-45.

Sicily/Sisilië 143.

Italy/Italië 1943-45.

The Sangro/Die Sangro.

Salerno.

Anzio.

Gustav Line/Gustav-linie.

Gothic Line/Gotiese linie.

Po/Appennines/Appenyne. 


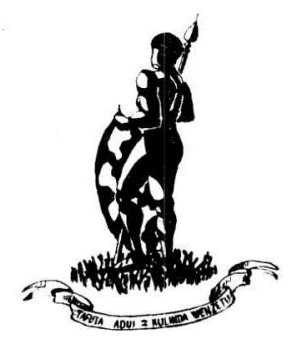

\section{Short History of No. 41 Squadron "S.A.A.F.}

1 Short History

a Squadron No. 41 was formed on October 16, 1940, with Maj. E. A. Pope as Officer Commanding. Arrangements were made to leave for East Africa on October 23, 1940.

b On December 16, 1940, "A" Flight with the exception of the pilots and four other ranks, and the advance parties for " $B$ " and " $C$ " Flights left Nakuru by road transport for Garissa. On December 18 " $A$ " Flight machines together with the remaining personnel left by air for Garissa and arrived safely. Headquarter flight and the remainder of " $\mathrm{B}$ and C" flights in convoy reached Garissa at 1400 hours.

On January 28, 1941 the Squadron machines participated in the attack on British Moyale. Positions were bombed and machinegunned in co-operation with the artillery.

On February 11 at 1500 hours "A and C" flights left for Afmada which had fallen during the day.

On February 23, 1941 orders were received for the Squadron to move on. "A and B" Flights proceeded ahead of the Headquarter Flight. On reaching Gelib the flights split once more and formed their own camps.

On February 25 "B" Flight ground party left for Brava at 0900 hours. Headquarter Flight and "A" Flight ground parties left at 0530 hours for Brava. "A and B" Flight machines left Gelib at sunrise for Brava.

On February 26 all Flights of the Squadron with the exception of " $C$ " Flight proceeded to Vittoria.

On February 27 the Flights moved to Mogadishu.

Mogadishu: March 4 orders were received from "B" Flight to proceed to, and operate from Bellet Uen. "C" Flight proceeded to Iscia Bardoa.

On March 20 "B" Flight arrived at Giggiga and were kept busy on sorties over the Maroa Pass.

March 22: Headquarters and "A" Flight ground party arrived at Giggiga at 1500 hours.

March 26: "C" Flight were instructed to move from Mogadishu to Giggiga where they arrived on 28 March.

March 29: The aerodrome was attacked by a Flight of 6 Fiats. Again there was a serious lack of anti-aircraft defence and the Fiats inflicted serious damage.

31 March: Headquarter and "A and B" Flights left for Dira Dawa. 
On April 6, 1941 orders were received for the Squadron to mure forward to Addis Ababa. On 7 April the Squadron moved into the capital of Abyssinia.

On May 6 when Emperor Haile Selassie entered Addis Ababa, precautions were taken in case of any outbursts of violence but the fears proved groundless.

Addis Ababa, June 1, 1941: The Squadron planes were brought up to a total strength of 24 by the transfer of a number of aircraft from No. 40 Squadron. The personnel of the unit was also strengthened by officers and men from the same unit.

August 2, 1941: For the first time in the history of the East African Campaign all Flights were operating from Alamatu. When Gondar fell on November 27, 1941, the final assault was made in conjunction with the ground forces. It was announced that the enemy forces taken at Gondar numbered 11500 Italian and 12000 native troops. Aircraft from " $\mathrm{C}$ " Flight dropped messages containing the terms of surrender to the remaining Italian positions at Celga.

January, 1942. The new camp at Gilgil was made very comfortable as it was surmised that the flight would have to remain there for some time.

On May 25, 1942, the Squadron Commander was informed that the proposed re-organisation of the Squadron had been agreed to. Sixteen Hurricanes were to be made available to arm two Flights. Two further Flights were to be armed with Hurricanes as soon as machines were available. In the interim a Hartbees was to be maintained by the Squadron for co-operation with the army. All other Hartbeeste were to be returned to the Union.

On November 10, 1942, the advance party arrived at Diredaua.

Maj. Hayden-Thomas arrived back from the Union on April 11, 1943, to take over command of the Squadron. He and Maj. Hughes addressed the Squadron about the new "V" oath for service anywhere in the world. Soon afterwards Lt.-Col. Galgut arrived from Nairobi and informed the Squadron that all squadrons were being moved out of East Africa. Those who had not signed the new oath were to be transferred to 16 Squadron.

c On the 12th May, 1943, the Squadron found itself at Shandur (North Africa, near Cairo) where they were stationed.

On June 18, 1943, Capt. Chapman (acting O.C.) reported to headquarters at El Adem and was instructed that the Squadron was to move to Bu Amud next week and that the aircraft strength was to be brought to 21 and the pilots are to total 30. Bu Amud was reached on July 2, 1943.

On July 23 an offensive was carried out against Crete. Official casualties for the sweep were: 13 fighters and 5 bombers. Six fighters were missing from this wing, including Squadron Leader Lee, who had led the Wing.

During the beginning of October 1943 the Squadron's Hurricane IIB's were replaced by IIC's.

From the 10th to the 31st of December 1943, the Squadron moved to E1 Adem and was then instructed to return to Bu Amud. This was a temporary arrangement as the Squadron was moved back to El Adem on January 8, 1944. From there it moved to Savoai where it arrived on January 31, 1944.

During the afternoon of February 24, 1944, 9 Spitfire IX's arrived for the Squadron. At the same time the Squadron moved to Sidi Barrani and arrived on the 26th. Again the Squadron moved, this time to arrive at Idku on the 2nd April 
From here it moved to El Gamil where it arrived on May 4, 1944.

At the close of June the Squadron was still located at Gamil w tachments at Lakatamia on Cyprus and at St. Jean near Haifa. From th Squadron moved to Almaza Base Camp on July 17, 1944.

e Yet again the Squadron moved, now to St. James were it arri August 6, 1944.

f On October 31, 1944, it was officially announced that the Squadr to be disbanded. The first group of personnel totalling 83 other ranks Almaza on November 5 by train. The remaining personnel proceeded $b$ convoy, one leaving on 6 and the other on November 8, 1944.

The unit was disbanded on October 30, 1944.

\section{Officers Commanding}

Maj. E. A. Pope : October 16, 1940-May 7, 1941.

Maj. D. M. van der Spuy (acting) : May 8, 1941-May 28, 1941.

Maj. G. T. Moll : May 29, 1941-April 20, 1942.

Maj. H. McG. Inglis : April 21, 1942-July/August, 1942.

Maj. P. J. Hayden-Thomas : August, 1942-February 17, 1943.

Capt. H. K. Alexander : February 18, 1943-March/April, 1943.

Maj. P. J. Hayden-Thomas : April, 1943-May, 1943.

Capt. C. Chapman (acting) : May 17, 1943-December 8, 1943.

Maj. G. C. Krummeck : December 9, 1943-July 21, 1944.

Capt. H. V. Bester (acting) : July 22, 1943-?

Capt. R. O. Burl (acting) : ?-September 26, 1944.

Maj. T. P. L. Murray, D.F.C. : September 27, 1944-November 19

\section{Battle Honours}

East Africa/Oos-Afrika 1940-41.

Addis Ababa.

The Juba/Die Juba.

The Lakes/Die Mere.

Mediterranean/Middellandse See 1942-45.

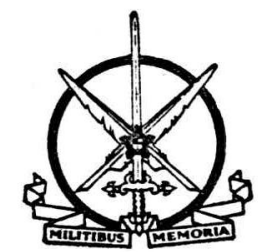

